\title{
BOVINE HERPESVIRUS TYPE 4: A SPECIAL HERPESVIRUS (REVIEW ARTICLE)
}

\author{
L. EGYED* \\ Veterinary Medical Research Institute of the Hungarian Academy of Sciences \\ H-1581 Budapest, P.O. Box 18, Hungary
}

(Received May 20, 2000; accepted October 17, 2000)

\begin{abstract}
This paper summarizes the history of and information on bovine herpesvirus type 4 (BoHV-4) from the first isolation to the most recent results. For almost twenty years BoHV-4 has been considered a typical herpes 'orphan' virus, which infects several species but causes no illness. The latest experiments revealed the close relationship of this virus with the immune system and other tissues. The virus was even considered as a possible candidate for a vector vaccine. BoHV-4 as a strange herpesvirus has several features which are not characteristic of other herpesviruses, such as several latency sites, persistence in serum, dividing cells necessary for virus replication, and the wide host range. In addition to describing the main features of the virion, replication, clinical signs, nomenclature problems, this review intends to concentrate on the new and strange results coming out from several laboratories worldwide. It is also suggested that because the virus combines several properties of various herpesvirus subfamilies and because of its close relationship with the immune system, it may deserve further attention as a representative of a potentially new genus within the Gammaherpesvirinae subfamily.
\end{abstract} replication

Key words: Bovine herpesvirus type 4, pathogenesis, latency, structure,

The first BoHV-4 strain was isolated in 1963 (Bartha et al., 1966), when pneumoenteritis due to type 4 bovine adenovirus was observed among 1- to 4month-old calves in a large farm in Western Hungary. Two to four weeks after recovery half of the animals developed keratoconjunctivitis. From an ocular swab a herpesvirus-like agent was isolated. Cytopathic effect, the susceptible cell types, and inclusion bodies were described. The virus was inactivated by heat, chloroform, and $\mathrm{pH} 3$. Neutralizing antibody levels were low, and the experimental infection of calves did not result in any clinical signs. Some years later a herpesvirus strain was found in the USA (Mohanty et al., 1971) with very similar properties. A new bovine herpesvirus was found.

*E-mail: laci@novell.vmri.hu; Fax: +36 (1) 467-4076 


\section{The virion}

BoHV-4 is a typical herpesvirus with an enveloped icosahedral nucleocapsid with a diameter of $150 \mathrm{~nm}$, containing a double-stranded DNA of $146 \mathrm{~kb}$. Twenty-nine structural proteins have been identified, ten of which are glycosylated. All the glycosylated proteins belong to the viral envelope, while a $140 \mathrm{~K}$ nonglycosylated protein appears to be the major nucleocapsid protein (Dubuisson et al., 1989). In gradients the virus has an equilibrium density of $1.2 \mathrm{~g} / \mathrm{cm}^{3}$, it is sensitive to $\mathrm{pH} 3,20 \%$ chloroform or ether, heat labile $\left(50{ }^{\circ} \mathrm{C}, 30 \mathrm{~min}\right)$, and all lipid solvents are good disinfectants.

\section{The virus-cell interaction}

Heparan sulphate serves as the initial receptor for several alphaherpesviruses and a betaherpesvirus. A study showed that during the process of absorption of BoHV-4 to the cell, a viral glycoprotein $135 \mathrm{~K}$ interacts with heparin-like molecules at the cell surface (Vanderplasschen et al., 1993). The $135 \mathrm{~K}$ protein (Gp8) is poorly glycosylated and present at both the viral envelope and in the culture medium (Dubuisson et al., 1992).

The virus replication cycle in the infected cell was followed by an electron microscopic study (McCoy et al., 1985), which showed that the multiplication of BoHV-4 is typical of other herpesviruses, the virus is replicated slowly, since the first labelled viruses were seen $6-12$ hours postinfection (PI) in the cytoplasmic vacuoles, while the newly synthesized virus particles appeared in the nucleus 12 to 24 hours PI. Envelope formation mainly occurred by budding at the nuclear membrane, but occasionally the virus budded into cytoplasmic vacuoles. Infectious particles were released from the cell at 48 hours PI. This type of replication has some characteristics similar to beta- and gammaherpesviruses, but not alphaherpesviruses. By comparing BoHV-4 L protein expression in lovastatinsynchronized MDBK cells, and in cells arrested in $\mathrm{G}_{\mathrm{o}}$ it was shown that the expression of viral genes (and probably virus multiplication) is dependent on the cell cycle. The $\mathrm{S}$ phase of the cell cycle increased viral DNA replication and protein expression, so BoHV-4 needs dividing cells for effective virus replication (Vanderplasschen et al., 1995).

\section{Nomenclature of the virus}

The nomenclature of the Movár-type virus has been confusing so far. Almost all isolates were given new names. The virus was called BHV-3, BHV-4, BHV-5, and bovine cytomegalovirus. The main experts of this type of virus drew 
a clear picture about taxonomy and nomenclature problems of the virus in 1987, and proposed to use the term 'bovine herpesvirus type 4' (BoHV-4) for the Movár-type viruses (Bartha et al., 1987). The international scientific community accepted this new name, and the virus is officially called BoHV-4.

\section{Host range}

In contrast to other beta- and gammaherpesviruses, bovine herpesvirus type 4 replicates in a wide variety of cell cultures, i.e., established primary cell cultures of cattle, sheep, goat, dog, cat, rabbit, pig and primary chicken kidney (Barahona et al., 1973). Various cell lines of these species are susceptible to BHV-4. The American reference strain (DN-599) was found to grow to high titres in mink lung and ferret kidney cells (Peterson and Goyal, 1988). Crandell feline kidney (CRFK) cells also support replication of BHV-4 (Kruger et al., 1990). Several species are susceptible to BHV-4 infection. The virus has been isolated from cattle (Barahona et al., 1973), American bison (Bison bison) (Todd and Storz, 1983), African buffalo (Syncerus caffer) (Rossiter et al., 1984), goats (Moreno-Lopez et al., 1989), non-ruminant species such as lions (A. Bartha, personal communication) and a cat suffering from urolithiasis (Fabricant et al., 1971). Simian herpesvirus aotus type 2, isolated from the kidney of an apparently normal owl monkey (Aotus trivirgatus), was proven to be a BHV-4 strain (Bublot et al., 1991). This monkey isolate replicated in four monkey cell lines [owl monkey kidney (OMK), squirrel monkey kidney, intestines, and lung cells (SMC), cebus monkey kidney (CMK), African green monkey kidney (Vero)], rabbit kidney (RK) and goat cells (GC), where cytopathic effect and inclusion bodies were observed. No cytopathic effect was seen in a primary culture of whole human embryo cells.

\section{Clinical signs and pathogenesis}

Bovine herpesvirus type 4 (BoHV-4) is a widespread agent of ruminants, especially cattle. Cattle populations of all continents are infected by this virus. BoHV-4 is often isolated from variety of clinical signs, inflammations, wounds, nasal, ocular genital swabs, postpartum metritis, aborted fetuses, but its role in these lesions is still not proven. Experimental infection of ruminants and laboratory animals (rabbits) resulted in only slight respiratory symptoms. Since the virus infects, and persists in, immune cells, possibility of an immunosuppressive effect was also suspected, but no compelling evidence was found so far. Isolation of different strains has been reported from animals showing a variety of clinical signs, such as conjunctivitis, pneumonia, inflammation of the upper respiratory tract (Mohanty et al., 1971), metritis (Parks and Kendrick, 1973), skin lesions 
(House et al., 1990), ulcerative mammillitis (Reed et al., 1977), enteritis (Eugster, 1979), and tumours of the urinary bladder and rumen (Kaminjolo et al., 1972). Viruses specified as BHV-4 were also detected in apparently healthy animals (Luther et al., 1971). The fact that BoHV-4 is associated with various symptoms and lesions indicates that this virus is probably not a causative agent of these clinical signs, but it seems to present itself as an activated latent virus in any place where local immunity is inhibited.

The natural infections probably occur through the respiratory and alimentary tracts, by inspired air or by the swallowing of virus aerosol or virus-infected cells. The virus replicates in epithelial cells of the intestines, larynx, trachea and bronchioles, causing slight catarrhal symptoms and fever. Virus multiplication occurs in peripheral blood leukocytes and the virus is disseminated in the host by these cells. From the apparently healthy animals the virus is continuously detected from the blood leukocytes, spleen, lymph nodes, for months (Osorio et al., 1982; Osorio and Reed, 1983; Osorio et al., 1985). Experimental inoculation of BHV-4 failed to elicit any clinical disease in cattle and sheep (Bartha et al., 1966), although pathogenicity by BHV-4 has been reported in rabbits (Osorio et al., 1982; Naeem et al., 1990, 1991) and cats (Kruger et al., 1990). The virus replicates in guinea pigs and rabbits; the latter species is an especially suitable laboratory model in BoHV-4 experiments (Naeem et al., 1990). We could detect signs of virus replication in rabbits, kittens, and guinea pigs by histological methods (Egyed et al., 1997). Sensitivity of the guinea pig to BoHV-4 was disputed, and the experiments showed contradictory results, while the susceptibility of cats to the virus was new in the literature. It is strange that a herpesvirus of a ruminant species infects a carnivorous species; however, it is in accordance with isolation of a BoHV-4 strain from lions (Bartha, unpublished).

With a nested polymerase chain reaction against the thymidine-kinase gene of the virus (Egyed et al., 1996) we could amplify specific DNA sequences, to detect 1-2 virus copies. The assay was specific (no cross-reaction with other equine or bovine herpesviruses was found).

We applied this sensitive method to follow the distribution of BoHV-4 in the infected host and to detect sites of persistence and latency. At PI day 48 the virus was found in 11 organs of experimentally infected calves. High amount of viral DNA accumulated in the nasal mucosa, trachea, lungs and spleen, and a lower amount in the lymph nodes, kidneys, tonsils, and thymus. The alimentary tract contained less virus, and a small amount was detected in the liver. The virus was mostly associated with the respiratory and immune tissues. In correlation with PCR results, with virus-specific monoclonal antibodies in immunohistochemistry cells were detected in the lungs and in the spleen, where active virus replication was going on at PI day 48. BoHV-4 appeared in leukocytes of experimental animals at PI day 2, and persisted in these cells throughout the experiment for 48 days. The number of virus-infected leukocytes was the highest at 
22-26 days, when one out of 10-100 cells carried viral genome. Later the number of infected cells decreased, but at 48 day one out of $10^{5}$ cells was virus infected. The long period of persistence and the high number of infected cells were surprising. Based on these results we suppose that the virus is able to inhibit the antiviral antibody mediated cellular immune response.

\section{Latency}

Establishing latency is a general feature of herpesviruses, when the viral genome in circular form remains in the nuclei, producing only a small amount of viral proteins. Alphaherpesviruses tend to be latent in the neurons, while betaand gammaherpesviruses in cells of the immune system. Under certain conditions (i.e. other infections, decreased host immune response) which are not known in detail so far, the virus can be reactivated. Cells and tissues produce infective virions, and the whole viral infective cycle starts again. Like other herpesviruses, BoHV-4 is able to establish latency, and can be reactivated from latent state (Castrucci et al., 1987). Several tissues and cell types have been considered as places of viral latency. Splenic mononuclear cells are the main site for viral persistence (Osorio and Reed, 1983; Lopez et al., 1996). Nervous tissues were considered as sites of viral latency, although the role of the nervous system in acute and latent BoHV-4 infections is still questionable. Trigeminal ganglia were taken from 44 clinically healthy cows and BoHV-4 was isolated from 2 of these animals (Homan and Easterday, 1981), but other authors could not detect virus in nervous tissues (Osorio et al., 1982). The nervous system has also been shown to be a possible site of BHV-4 latency in other studies (Krogman and McAdaragh, 1982; Naeem et al., 1991). Despite these reports, BoHV-4 was not detected or isolated from most brain samples from experimentally or naturally infected animals. We studied the possible sites of BoHV-4 latency by PCR for 60 days after experimental infection of calves, when no shed virus had been detected for two weeks. Viral DNA was not only detected in immune cells (spleen, bone marrow, lymph nodes) but in cells of the nervous system (spinal cord, trigeminal ganglia, hippocampus, medulla oblongata) as well. Thus we concluded that BoHV-4 is able to establish latency in the immune and nervous system, uniting features of herpesvirus subfamilies (Egyed and Bartha, 1998).

\section{Effect on the immune functions}

The main reason why virologists turned to BoHV-4 was a possible immunosuppressive effect of the virus on the host immune functions. Persistence and frequent isolations from cells of the immune system (spleen, blood leukocytes) 
indicate some relation to the immune response, but despite the work of several research groups, we still have no strong evidence about a direct inhibitory effect of BoHV-4 on any immune functions. In our laboratory we studied the in vivo cellular immune response in virus-infected rabbits by intradermal inoculation of mitogens (pokeweed, phytohaemagglutinin, concanavalin A). No significant difference was found between the skin thickness of inoculated and control animals. Humoral immune response against various antigens was not altered in virusinoculated animals. The only possible immunosuppressive sign was that the virus decreased the in vitro division activity of $\mathrm{H}^{3}$-labelled leukocytes. These results indicate that the virus is able to infect, and probably replicate in, certain immune cells, and slightly impair their functions. However, the exact type of infected cells and the type of the altered immune function are not unknown.

\section{The viral genome}

The virus has a genome of approximately $146 \mathrm{~kb}$ which contains a large unique region of $110 \mathrm{~kb}$ flanked on both ends by multiple tandem copies of a 1.5-3 kb region known as polyrepetitive (pr) DNA (Broll et al., 1999a). The size of this repeat unit varies among isolates. The number of copies of prDNA at each end of the linear genome varies, but the overall number per genome is approximately 15 (Ehlers et al., 1985). Restriction maps of the viral genome completely differed from those of other bovine herpesviruses, but the genetic relatedness is very high among BoHV-4 isolates (van Santen and Chang, 1992; Shen et al., 1992). The differences between BoHV-4 isolates can be detected both in the unique segment and in the prDNA. BoHV-4 strains can be classified into two groups by restriction endonuclease cleavage by EcoRI, BamHI, and HindIII enzymes. The differences are most evident and visible by HindIII digestion. Almost all American isolates are DN-599-like strains, while the Movár 33/63-like group comprises all European strains (Bublot et al., 1990).

Several genes were examined in detail by various authors. Sequencing glycoprotein B gene helped to estimate the phylogenetic relationship among herpesviruses. The results showed that Epstein-Barr virus and Herpesvirus saimiri are closest to BoHV-4 on the evolutionary tree (Goltz et al., 1994). Studying immediate early (IE) gene products (one of them is the thymidine kinase TK gene) helped to understand the regulation of certain genes in detail, their promoter regions and transactivation mechanisms (Kit et al., 1986; Lomonte et al., 1992; Chang and van Santen, 1992; van Santen, 1993; Chang and van Santen, 1995).

Although the nucleotide sequence of the viral genome is still not completely known in detail, over the last years some genomic regions and genes have been sequenced, providing further data on the classification and understanding of this agent. 
Some genes which were important in certain experiments have been sequenced (thymidine kinase, glycoprotein B, immediate-early gene etc.), but sequences of long regions are not known so far. In the genome five genome blocks were found ( $58 \%$ of the total genome), with clustered genes, whose orientation and location in the genome are conserved in the herpesvirus subfamily. Between these blocks lie genes specific to the particular virus. These BoHV-4-specific genomic regions were sequenced between the five blocks (Lomonte et al., 1996). Twelve open reading frames (ORF) were found, translation products of five ORFs were homologous in amino acid sequences to proteins encoded by Herpesvirus saimiri, and one was similar to proteins encoded by both Herpesvirus saimiri and the human Epstein-Barr virus (human herpesvirus type 4). None of these 12 ORFs showed similarity to alpha- or betaherpesviruses, indicating that BoHV-4 is a gammaherpesvirus.

HindIII B fragment of the genome (10456 bp) was sequenced (Broll et al., $1999 b$ ) with nine complete and two incomplete open reading frames (majorminor capsid proteins, protein kinase, cleavage/packaging proteins). The genes were homologous to Herpesvirus saimiri, Epstein-Barr virus, and human herpesvirus type 8 (Kaposi sarcoma associated herpesvirus). On the basis of these sequence data and based on the phylogenetic analysis of proteins, BoHV-4 was placed in the genus Rhadinovirus of the subfamily Gammaherpesvirinae.

To investigate the structure and functional role of polyrepetitive DNA (prDNA), the complete nucleotide sequence of a cloned prDNA unit (2267 bp) was determined. Moreover, terminal fragments of the genome and the junction region between prDNA and central unique DNA were analysed. In the prDNA (with $71.1 \% \mathrm{G} / \mathrm{C}$ content) every unit contains a cis-acting cleavage/packaging signal. A 443 bp long fragment was found, which comprises the cleavage/packaging signal sufficient for cleavage and encapsidation of replicated viral DNA.

Based on the above molecular data about the viral genome, the International Committee for the Taxonomy of Viruses assigned BoHV-4 to the Gammaherpesvirinea subfamily (Roizman et al., 1992).

\section{DNA detection methods}

DNA hybridization has also been used as diagnostic tool (Galik et al., 1992). Ten picograms of purified viral DNA was detected by using 11- and $5.7 \mathrm{kbp}$ HindIII fragments of BoHV-4 as probes.

To detect BoHV-4 DNA from samples of organs from experimentally infected rabbits, a single PCR assay was developed by using the sequence data of the EcoRI-L fragment of viral DNA. This assay was able to detect 100 fentograms of viral DNA (approximately 6000 virus particles). These primers cross- 
reacted with bovine cells, thus they were not suitable for the detection of BHV-4 in specimens of bovine origin (Naeem et al., 1991).

Polymerase chain reaction (PCR) assays have been developed, providing a specific and sensitive tool for viral DNA detection (Egyed et al., 1996; Lin et al., 2000).

\section{Serology}

Virus neutralization is not a suitable method for antibody detection (van Opdenbosch et al., 1988), since during natural infections no detectable neutralizing antibodies are produced. Polyvalent sera show low neutralizing activity; by adding extra guinea pig complement, only pairs of monoclonal antibodies could neutralize the virus (Dubuisson et al., 1990). BoHV-4 specific antibodies are demonstrated by complement fixation, dot immunobinding assay, agar gel immunodiffusion assay, immunofluorescence assay, or enzyme-linked immunosorbent assays (ELISAs) (Sass et al., 1974; Edwards and Newman, 1985; Guo et al, 1988). The direct detection of the virus is based on virus isolation and characterization of specific letter-shaped inclusion bodies (Augsburger and Metzler, 1989).

Recently a new, sensitive serological method has been developed to detect BoHV-4 specific antibodies (Wellenberg et al., 1999). The immunoperoxidase monolayer assay (IPMA) could detect all immunoglobulin subclasses. The method proved to be more sensitive than an indirect ELISA method, since IPMA could detect BoHV-4 specific antibodies at PI day 16-18 from experimentally infected cattle, two weeks earlier than the ELISA test. The method allowed a serological survey of the Dutch cattle population for BoHV-4 incidence, which showed $18 \%$ seroprevalence.

Since BoHV-4 infection is characterized by a very low neutralizing antibody response, or by the absence of neutralizing antibodies, cellular immune response plays a key role in the host's antiviral immune response. An interferon- $\gamma$ assay was developed to detect and study the cell-mediated immunity in cattle after bovine herpesvirus 4 infection (Godfroid et al., 1996). The in vitro antigenspecific interferon gamma release assay as an indicator of an actively acquired immunity resulted in measurable cell-mediated immunity in $44.4 \%$ at a farm with $76.3 \%$ seropositivity, while in a seronegative farm all the tested samples were negative by IFN- $\gamma$ release assay. The test could be useful in basic research for studying the interactions between the virus and the host immune system.

\section{New fields of BoHV-4 studies}

A new aspect of BoHV-4 is its possible role in damaging vascular tissues, especially endothelial cells, and such focal inflammations could lead to further 
vascular diseases, atherosclerosis and thrombosis as it was shown in Chlamydia pneumoniae and murine cytomegalovirus infections.

BoHV-4 was found to replicate in bovine alveolar endothel cell line (BAE) in vitro (Lin et al., 1997). Established primer cell culture of bovine carotid arteries was also susceptibly to the virus (Lin et al., 1999). Furthermore, BoHV -4 seems to accelerate the atherosclerotic process in rabbits experimentally fed a $2 \%$ cholesterol diet (Lin et al., 2000). It is still questionable whether BoHV-4 could induce atherosclerosis alone since cholesterol is a well-known atherosclerosis inducer. If further studies strengthen these results BoHV-4 infection in rabbits could be a suitable animal model in vascular disease or atherosclerosis research.

Phylogenetic analysis and studies on the viral genome helped to classify BoHV-4 as a gammaherpesvirus. For more than twenty years the virus was considered as bovine cytomegalovirus because of some common features that BoHV-4 shares with cytomegaloviruses. Phylogenetic studies (Goltz et al., 1994; Karlin et al., 1994) and data obtained from analysis of the viral genome (Lomonte et al., 1996) indicated the same results, i.e. that BoHV-4, herpesvirus saimiri (HSV) and Epstein-Barr virus (EBV) are gammaherpesviruses, distinct and separate from other herpesvirus classes. BoHV-4 as a $\gamma-2$ herpesvirus is more closely related to HSV than to EBV.

The virus-infected host usually defends the infected tissues from virus production by a process called apoptosis. During apoptosis certain cells 'commit suicide' by cutting the virus genome into 100-200 bp long fragments. Virusinfected cells tend to switch on apoptosis, thereby reducing the number of infective progeny of the virus. Lots of viruses encode proteins which inhibit apoptosis to prolong survival of infected cells. BoHV-4 was found to have a gene in the BORFE2 region, which inhibits Fas- and TNFR1-induced apoptosis and interacts with caspase- 8 and effector enzyme of regulation of apoptosis (Wang et al., 1997). This gene is a novel feature of BoHV-4, a further proof for the close interaction between the virus and the host immune system.

During viral infections viruses can get into the bloodstream as virions or in infected leukocytes. Herpesviruses (Epstein-Barr virus, human cytomegalovirus) often establish life-long persistence or latency in leukocytes. Viruses and the large majority of virus-infected cells are eliminated by virus-specific antibody mediated immune response. Studying BoHV-4 in the serum of naturally infected calves we found that the virus appeared 5-6 times with a 10-day-long periodicity for 1-2 days (Egyed et al., 1999). When naturally infected calves were also inoculated in experimental way, the viral DNA appeared in the serum for 1-2 days, but the 10-day-long periodicity was not observed, probably because two infections were going on at the same time in the animal. The viral DNA appeared in the serum for 60 days in newborn calves, for 35 days in 2-4 months old animals. Viral DNA was detected in the serum of rabbits infected experimentally twice, 
with a 14-day interval. The DNA was detected by PCR, so we do not know whether infective virus particles, capsids or DNA molecules were present in the serum.

BoHV-4 (like BoHV-2) was able to replicate on human embryonic lung cells (Wistar-38, MRC-5) and on a primary cell culture from a human glyoblastoma in vitro, which is a rare phenomenon for animal herpesviruses (Egyed and Bartha, 1998).

The virus could be an important target of veterinary research, not because of the economic losses the virus causes, but because it is a good basic research model for studying herpesviruses. Since this virus combines several properties of alpha-, beta- and gammaherpesviruses (replicates in various species and cell lines, latent in the immune and nervous system), it may deserve further attention as a representative of a potentially new genus within the Gammaherpesvirinae subfamily.

\section{References}

Augsburger, H. R. and Metzler, A. E. (1989): In vitro growth characteristics of bovine herpesvirus 4 (BHV-4) as revealed by indirect immunofluorescence assay with monoclonal antibodies and polyvalent antisera. Arch. Virol. 104, 309-321.

Barahona, H. H., Melendez, L. V., King, N. W., Daniel, M. D., Fraser, C. E. O. and Preville, A. C. (1973): Herpesvirus aotus type 2: A new viral agent from owl monkeys (Aotus trivirgatus). J. Infect. Dis. 127, 171-178.

Bartha, A., Fadol, A. M., Liebermann, H., Ludwig, H., Mohanty, S. B., Osorio, F. A., Reed, D. E. Storz, J., Straub, O. C., van der Maaten, M. J. and Wellemans, G. (1987): Problems concerning the Movar type bovine herpesviruses. Intervirology 28, 1-7.

Bartha, A., Juhász, M. and Liebermann, H. (1966): Isolation of a bovine herpesvirus from calves with respiratory disease and keratoconjunctivitis. Acta Vet. Acad. Sci. Hung. 16, 357-358.

Belák, S. and Pálfi, V. (1974): Characterization of a herpesvirus isolated from spontaneously degenerated bovine kidney cell culture. Acta Vet. Acad. Sci. Hung. 24, 249-253.

Broll, H., Buhk, H.-J., Zimmermann, W. and Goltz, M. (1999a): Structure and function of the prDNA and the genomic termini of the $\gamma 2$-herpesvirus bovine herpesvirus type 4. J. Gen. Virol. 80, 979-986.

Broll, H., Finsterbush, T., Buhk, H.-J. and Goltz, M. (1999b): Genetic analysis of the bovine herpesvirus type 4 gene locus for the putative terminase. Virus Genes 19, 243-250.

Bublot, M., Dubuisson, J., Van Bressem, M. J., Danyi, S., Pastoret, P. P. and Thiry, E. (1991): Antigenic and genomic identity between simian herpesvirus aotus type 2 and bovine herpesvirus type 4. J. Gen. Virol. 72, 715-719.

Bublot, M., Van Bressem, M. F., Thiry, E., Dubuisson, J. and Pastoret, P. P. (1990): Bovine herpesvirus 4 genome: cloning, mapping and strain variation analysis. J. Gen. Virol. 71, 133-142.

Castrucci, G., Frigeri, F., Ferrari, M., Cilli, V., Aldrovendi, V., Rampichini, L. and Gatti, R. (1987): A study of the pathogenesis of bovid herpesvirus-4 in calves. J. Vet. Med. B 34, 473-479.

Chang, L. Z. and van Santen, V. L. (1992): Immediate-early and late RNAs in bovine herpesvirus4-infected cells. Virology 191, 909-920.

Chang, L. Z. and van Santen, V. L. (1995): Interaction of bovine herpesvirus 4 (BHV-4) immediate early 2 gene product with BHV-4 thymidine kinase promoter regulatory region. J. Gen. Virol. 76, 2433-2445. 
Dubuisson, J., Boulanger, D., Bublot, M., Thiry, E. and Pastoret, P. P. (1989): Proteins specified by bovine herpesvirus type 4: structural proteins of the virion and identification of two major glycoproteins by using monoclonal antibodies. J. Gen. Virol. 70, 1743-1753.

Dubuisson, J., Guillaume, J., Boulanger, D., Thiry, E., Bublot, M. and Pastoret, P. P. (1990): Neutralization of bovine herpesvirus type 4 by pairs of monoclonal antibodies raised against two glycoproteins and identification of antigenic determinants involved in neutralization. J. Gen. Virol. 71, 647-653.

Dubuisson, J., Koromyslov, I., Pastoret, P. P. and Thiry, E. (1992): Proteins of bovine herpesvirus type 4 released into the culture medium of productively infected cells: identification of a $135 \mathrm{~K}$ protein glycoprotein involved in viral attachment. J. Gen Virol. 73, 189-194.

Edwards, S. and Newman, R. H. (1985): Detection of antibodies to bovid herpesvirus-4 by ELISA. Vet. Microbiol. 10, 149-154.

Egyed, L. and Bartha, A. (1998): PCR studies on the potential sites for latency of BHV-4 in calves. Vet. Res. Commun. 22, 209-216.

Egyed, L., Ballagi-Pordány, A., Bartha, A. and Belák, S. (1996): Studies of in vivo distribution of bovine herpesvirus type 4 in the natural host. J. Clin. Microbiol. 34, 1091-1095.

Egyed, L., Berencsi, Gy. and Bartha, A. (1999): Periodic reappearance of bovine herpesvirus type 4 (BHV-4) DNA in the sera of naturally and experimentally infected rabbits and calves. Comp. Immunol. Microbiol. Infect. Dis. 22, 199-206.

Egyed, L., Kluge, J. P. and Bartha, A. (1997): Histological studies of bovine herpesvirus type 4 infection in non ruminant species. Vet. Microbiol. 51, 283-289.

Ehlers, B., Buhk, H. J. and Ludwig, H. (1985): Analysis of bovine cytomegalovirus genome structure: Cloning and mapping of the monomeric polyrepetitive DNA unit, and comparison of European and American strains. J. Gen. Virol. 66, 55-68.

Eugster, A. K. (1979): Isolation of bovine herpesvirus III from diarrheic faeces. Vet. Microbiol. 3, 199-204.

Fabricant, C. G., Gillespie, J. H. and Krook, L. (1971): Intracellular and extracellular mineral crystal formation induced by viral infection of cell cultures. Infect. Immun. 3, 416-419.

Galik, P. K., van Santen, V. L., Stringfellow, D. A., Bird, R. C., Wright, J. C. and Smith, P. C. (1992): Development of a DNA probe for identification of bovine herpesvirus 4. Am. J. Vet. Res. 54, 653-659.

Godfroid, J., Czaplicki, G., Kerkhofs, P., Weynants, V., Wellemans, G., Thiry, E. and Letesson, J. J. (1996): Assessment of the cell-mediated immunity in cattle after bovine herpesvirus 4 infection, using an in vitro antigen-specific interferon- $\gamma$ assay. Vet. Microbiol. 53, 133-141.

Goltz, M., Broll, H., Mankertz, A., Weigelt, W., Ludwig, H., Buhk, H. J. and Brochers, K. (1994): Glycoprotein B of bovine herpesvirus type 4: Its phylogenetic relationship to gB equivalents of the herpesviruses. Virus Genes 9, 53-59.

Goyal, S. M. and Naeem, K. (1992): Bovid herpesvirus-4: a review. Vet. Bulletin. 62, 181-201.

Guo, W. Z., Shen, D. T., Everman, J. F. and Gorham, J. R. (1988): Comparison of an enzymelinked immunosorbent assay and a complement-fixation test for the detection of $\operatorname{IgG}$ to bovine herpesvirus type 4 (bovine cytomegalovirus). Am. J. Vet. Res. 49, 667-670.

Homan, E. J. and Easterday, B. C. (1981): Further studies of naturally occurring latent bovine herpesvirus infection. Am. J. Vet. Res. 42, 1811-1813.

House, J. A., Wilson, T. M., El Nakashly, S., Karim, L. A., Ismail, L., El Danaf, N., Moussa, A. M. and Ayoub, N. N. (1990): The isolation of lumpy skin disease virus and bovine herpesvirus 4 from cattle in Egypt. J. Vet. Diagn. Invest. 2, 111-115.

Kaminjolo, J. S. Jr., Mugera, G. M. and Rosted, A. F. (1972): Isolation of a herpes-type virus from some tumours of bovine origin. Zbl. Vet-med. B 19, 626-632.

Karlin, S., Mocarski, E. S. and Schachtel, G. A. (1994): Molecular evolution of herpesviruses: genomic and protein sequence comparisons. J. Virol. 68, 1886-1902. 
Kit, S., Kit, M., Ichimura, H., Crandell, R. and McConnel, S. (1986): Induction of thymidine kinase activity by viruses with group B DNA genomes; bovine cytomegalovirus (bovine herpesvirus 4). Virus Res. 4, 197-212.

Krogman, L. A. and McAdaragh, J. P. (1982): Recrudescence of bovine herpesvirus-5 in experimentally infected calves. Am. J. Vet. Res. 43, 336-338.

Kruger, J. M., Osborne, C. A., Goyal, S. M., Pomeroy, K. A. and O’Brien, T. D. (1990): Clinicopathologic and pathologic findings of herpesvirus-induced urinary tract infection in conventionally reared cats. Am. J. Vet. Res. 51, 1649-1655.

Lin, T. M., Shi, G. Y., Tsai, C. F., Su, H. J., Guo, Y. L. L. and Wu, H. L. (1997): Susceptibility of endothelial cells to bovine herpesvirus type 4 (BHV-4). J. Virol. Methods 63, 219-225.

Lin, T. M., Shi, G. Y., Jiang, M. J., Tsai, C. F., Hwang, B. J., Hsieh, C. T. and Wu, H. L. (1999): Persistent infection of bovine herpesvirus type 4 in bovine endothelial cell cultures. Vet. Microbiol. 70, 41-53.

Lin, T. M., Jiang, M. J., Eng, H. L., Shi, G. Y., Lai, L. C., Huang, B. J., Huang, K. Y. and Wu, H. L. (2000): Experimental infection with bovine herpesvirus-4 enhances atherosclerotic process in rabbits. Lab. Invest. 80, 3-11.

Lomonte, P., Bublot, M., Pastoret, P. P. and Thiry, E. (1992): Location and gene comparison with thymidine kinase gene of other herpesviruses. Arch. Virol. 127, 327-337.

Lomonte, P., Bublot, M., van Santen, V., Keil, G. M., Pastoret, P. P. and Thiry, E. (1995): Analysis of bovine herpesvirus 4 genomic regions located outside the conserved gammaherpesvirus gene blocks. J. Gen. Virol. 76, 1835-1841.

Lomonte, P., Bublot, M., van Santen, V., Keil, G., Pastoret, P. P. and Thiry, E. (1996): Bovine herpesvirus 4: genomic organization and relationship with two other gammaherpesviruses, Epstein-Barr virus and herpesvirus saimiri. Vet. Microbiol. 53, 79-89.

Lopez, O. J., Galeota, J. A. and Osorio, F. A. (1996): Bovine herpesvirus type-4 (BHV-4) persistently infects cells of the marginal zone of spleen in cattle. Microbial Pathogenesis 21, 47-58.

Luther, P. D., Bradley, P. G. and Haig, D. A. (1971): The isolation and characterization of a herpesvirus from calf kidney cell cultures. Res. Vet. Sci. 12, 496-498.

McCoy, S. B., Mohanty, S. B. and Rockeman, D. D. (1985): Electron microscope autoradiographic study of bovine herpesvirus 4. Zbl. Vet. Med. B 32, 368-374.

Mohanty, S. B., Hammond, R. C. and Lillie, M. G. (1971): A new bovine herpesvirus and its effect on experimentally infected calves. Arch. ges. Virusforsch. 33, 394-395.

Moreno-Lopez, J., Goltz, M., Rehbinder, C., Valsala, K. V. and Ludwig, H. (1989): A bovine herpesvirus (BHV-4) as passenger virus in ethmoidal tumours in Indian cattle. J. Vet. Med. B 36, 481-486.

Naeem, K., Caywood, D. D., Werdin, R. E. and Goyal, S. M. (1990): Evaluation of pregnant rabbits as a laboratory model for bovid herpesvirus-4 infection. Am. J. Vet. Res. 51, 640-644.

Naeem, K., Murtaugh, M. P. and Goyal, S. M. (1991): Tissue distribution of bovid herpesvirus-4 in inoculated rabbits and its detection by DNA hybridization and polymerase chain reaction. Arch. Virol. 119, 239-255.

Osorio, F. A. and Reed, D. E. (1983): Experimental inoculation of cattle with bovine herpesvirus-4: evidence for a lymphoid-associated persistent infection. Am. J. Vet. Res. 44, 975-980.

Osorio, F. A., Reed, D. E. and Rock, D. L. (1982): Experimental infection of rabbits with bovine herpesvirus-4: acute and persistent infection, Vet. Microbiol. 7, 503-513.

Osorio, F. A., Rock, D. L. and Reed, D. E. (1985): Studies on the pathogenesis of a bovine cytomegalo-like virus in an experimental host. J. Gen. Virol. 66, 1941-1951.

Parks, J. B. and Kendrick, J. W. (1973): The isolation and partial characterization of a herpesvirus from a case of bovine metritis. Arch. ges. Virusforsch. 41, 211-215.

Peterson, R. B. and Goyal, S. M. (1988): Propagation and quantitation of animal herpesviruses in eight cell culture systems. Comp. Immunol. Microbiol. Infect. Dis. 11, 93-98.

Reed, D. E., Langpap, T. J. and Anson, M. A. (1977): Characterization of herpesviruses isolated from lactating dairy cows with mammary pustular dermatitis. Am. J. Vet. Res. 38, 1631-1634. 
Roizman, B., Desroisers, R. C., Fleckenstein, B., Lopez, C., Minson, A. C. and Studdert, M. J. (1992): The family Herpesviridae: an update. Arch. Virol. 123, 425-449.

Rossiter, P. B., Gumm, I. D., Stagg, D. A., Conrad, P. A., Mukolwe, S., Davies, F. G. and White, H. (1984): Isolation of bovine herpesvirus-3 from African buffaloes (Syncerus caffer). Res. Vet. Sci. 46, 337-343.

Sass, B., Mohanty, S. B. and Hetrick, F. M. (1974): Fluorescent antibody study of a new bovine herpesvirus (strain DN 599). Am. J. Vet. Res. 35, 1343-1346.

Shen, D. T., Burger, D., Tong, G. Z. and Gorham, J. R. (1992): Molecular cloning and physical mapping of bovine herpesvirus 4 strain DN 599 and comparison with two American field isolates. Arch. Virol. 127, 75-87.

Thiry, E., Bublot, M., Dubuisson, J., Van Bressem, M.-F., Lequarre, A.-S., Lomonte, P., Vanderplasschen, A. and Pastoret, P.-P. (1992): Molecular biology of bovine herpesvirus type 4. Vet. Microbiol. 33, 79-92.

Todd, W. J. and Storz, J. (1983): Morphogenesis of a cytomegalovirus from an American bison affected with malignant catarrhal fever. J. Gen. Virol. 64, 1025-1030.

Vanderplasschen, A., Bublot, M., Dubuisson, J., Pastoret, P. P. and Thiry, E. (1993): Attachment of the gammaherpesvirus bovine herpesvirus 4 is mediated by the interaction of gp8 glycoprotein with heparinlike moieties on the cell surface. Virology 196, 232-240.

Vanderplasschen, A., Goltz, M., Lyaku, J., Benarafa, C., Buhk, H. J., Thiry, E. and Pastoret, P. P. (1995): The replication in vitro of the gammaherpesvirus bovine herpesvirus 4 is restricted by its DNA synthesis dependence on the S phase of the cell cycle. Virology 213, 328-340.

Van Opdenbosch, E., Wellemans, G., Ooms, L. A. A. and Degryse, A. D. A. Y. (1988): BHV-4 (bovine herpesvirus 4) related disorders in Belgian cattle. A study of two problem herds. Vet. Res. Commun. 12, 347-353.

Van Santen, V. L. (1993): Characterization of a bovine herpesvirus 4 immediate-early RNA encoding a homolog of the Epstein-Barr virus R transactivator. J. Virol. 67, 773-784.

Van Santen, V. L. and Chang, L. Y. (1992): Cloning and mapping of EcoRI, HindIII and PstI fragments of bovine herpesvirus 4 (DN-599) genome. Intervirology 34, 44-52.

Wang, G. H., Bertin, J., Wang, Y., Martin, D. A., Wang, J., Tomaselli, K. J., Armstrong, R. C. and Cohen, J. I. (1997): Bovine herpesvirus 4 BORFE2 protein inhibits fas- and tumor necrosis factor receptor 1-induced apoptosis and contains death effector domains shared with other gamma-2 herpesviruses. J. Virol. 71, 8928-8932.

Wellenberg, G. J., van Rooij, E. M. A., Maissan, J. and van Oirshot, J. T. (1999): The evaluation of a newly developed immunoperoxidase monolayer assay to detect antibodies against bovine herpesvirus 4. XIth Int. Congress of Virology, Sydney. Abstract, p. 234. 